\title{
Propranolol in supraventricular tachycardias of childhood
}

\author{
PAUL H. DWORKIN, BARBARA B. BELL, and M. MIROWSKI \\ From the Department of Pediatrics, The Johns Hopkins University School of Medicine; and \\ Department of Medicine, Sinai Hospital, Baltimore, Maryland, U.S.A.
}

Dworkin, P. H., Bell, B. B., and Mirowski, M. (1973). Archives of Disease in Childhood, 48, 382. Propranolol in supraventricular tachycardias of childhood. 9 children with supraventricular tachycardias refractory to conventional therapy were treated with propranolol. In 3 children normal sinus rhythm was restored. In 3 others frequency of paroxysmal arrhythmias was decreased. In 1 reduction of ventricular response to the ectopic rhythm was achieved, and in 2 remaining patients, propranolol had no effect. The dosage of propranolol ranged from 0.5 to $4.0 \mathrm{mg} / \mathrm{kg}$ per day, given orally, with few side effects. It appears that propranolol can play an important role in treatment of supraventricular arrhythmias of childhood unresponsive to conventional therapy.

Supraventricular tachycardias represent an important management problem in paediatrics. While digoxin is the drug of choice, propranolol has been proposed for arrythmias refractory to conventional therapy. The mode of action of propranolol is well known (Schamroth, 1966). However, its optimal paediatric dosage, as well as long-term effects and side effects in children, remains to be determined.

In this study, records of 9 children with refractory supraventricular tachycardia treated with propranolol and digoxin have been examined in order to (1) ascertain whether any systematized approach to the use of this drug has been employed; (2) determine the indications for its use in such patients; (3) develop criteria for evaluation of propranolol's effectiveness; and most importantly (4) provide a basis for carefully devised prospective studies and a rational therapeutic approach.

\section{Materials and methods}

Between 1961 and 1971, 58 children were primarily treated for supraventricular tachycardias in this institution. Of these, 9 did not respond to conventional therapy and were treated with propranolol. Clinical and ECG records of these children were examined. 8 had idiopathic supraventricular tachycardias without evidence of structural heart disease, confirmed by cardiac catheterization in 3 (Cases 1,3 , and 4 ). The remaining patient developed the arrhythmia after Mustard procedure for complete transposition of the great vessels

Received 25 September 1972.
(Case 2). The patients' ages ranged from 9 inonths to 16 years. There were 7 males and 2 females. All were symptomatic with dyspnoea, dizziness, chest pain, or epigastric distress. In all children, reflex vagal stimulation and sedation were attemptea. Previous therapy with digoxin alone, digoxin, and/or cardioversion and/or quinidine had also been unsuccessful in achieving and maintaining a satisfactory ventricular rate. The effectiveness of propranolol was judged by its ability to convert the arrhythmia to sinus rhythm, to slow the ventricular response to physiological values even during exercise if the abnormal rhythm persisted, or to decrease the frequency of paroxysmal attacks. In all patients digoxin was continued. The pertinent clinical and ECG data are summarized in the Table.

\section{Results}

Striking clinical improvement was observed in 8 patients. In 3 (Cases 3, 4, and 9) sinus rhythm was restored (Fig. 1). In 1 (Case 9) propranolol was helpful in maintaining sinus rhythm after cardioversion. In another patient with atrial flutter (Case 2) an increase in the degree of AV block established a satisfactory ventricular rate without conversion of the arrhythmia, though sinus rhythm was eventually restored (Fig. 2). In 3 other children, frequency of paroxysmal attacks was reduced from daily to weekly occurrence (Cases 1, 7, and 8). In only 1 child no improvement was observed (Case 6); in another, reversion to sinus rhythm was probably not due to propranolol (Case 5) The dosage of propranolol ranged from 0.5 to $4.0 \mathrm{mg} / \mathrm{kg}$ per day by mouth. 

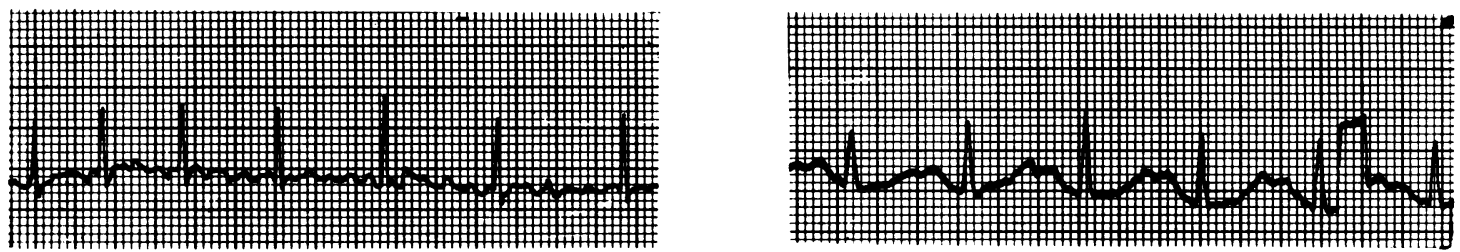

FIG. 1.-Conversion of atrial flutter-fibrillation to normal sinus rhythm after addition of propranolol.

The follow-up of these patients ranged from $3 \frac{1}{2}$ to 30 months, with a mean of 13 months.

Few side effects were observed. Those noted include the development of sinus bradycardia (Cases 1 and 8), feeding difficulties (Case 3), and aggravation of ketotic hypoglycaemia (Case 2); this led to decrease in dosage in 3 patients (Cases 1 , 2 , and 3).

\section{Discussion}

While the effectiveness of propranolol as an antiarrhythmic agent has been widely documented in the adult population (Wennevold and Sandoe, 1966; Luria, Adelson, and Miller, 1966; Sloman and Stannard, 1967), far less information is available concerning its use in children. By means of $\beta$-adrenergic blockade and also through a direct

TABLE

Clinical features and response to therapy

\begin{tabular}{|c|c|c|c|c|c|c|c|c|c|}
\hline \multirow{2}{*}{$\begin{array}{l}\text { Case no. } \\
\text { and } \\
\text { sex }\end{array}$} & \multirow{2}{*}{$\begin{array}{l}\text { Age } \\
(\mathbf{y r})\end{array}$} & \multirow[b]{2}{*}{ ECG } & \multirow{2}{*}{$\begin{array}{c}\text { Rate/ } \\
\text { min }\end{array}$} & \multirow{2}{*}{$\begin{array}{c}\text { Unsuccessful } \\
\text { therapy }\end{array}$} & \multirow{2}{*}{$\begin{array}{c}\text { Weight } \\
(\mathbf{k g})\end{array}$} & \multicolumn{2}{|c|}{ Propranolol } & \multirow[b]{2}{*}{ Results§ } & \multirow[b]{2}{*}{ Side effects } \\
\hline & & & & & & $\begin{array}{c}\text { Dose (oral) } \\
\text { (mg/kg per day) }\end{array}$ & $\begin{array}{c}\text { Duration } \\
\text { (mth) }\end{array}$ & & \\
\hline $\begin{array}{r}1 \\
M\end{array}$ & $122 / 12$ & $\begin{array}{l}\text { Atrial flutter; } \\
\text { junctional } \\
\text { rhythm }\end{array}$ & 280 & Digoxin & 40 & $\begin{array}{l}\star 0.3 \text { to } \\
3 \text { then to } \\
0.5\end{array}$ & 13 & + & Bradycardia \\
\hline$\stackrel{2}{M}$ & $26 / 12$ & Atrial flutter & 160 & $\begin{array}{l}\text { Digoxin; } \\
\text { cardio- } \\
\text { version; } \\
\text { quinidine }\end{array}$ & $12 \cdot 5$ & $\star^{\star} 1.5$ to & 7 & ++ & $\begin{array}{l}\text { Aggravation of } \\
\text { of ketotic } \\
\text { hypogly- } \\
\text { caemia }\end{array}$ \\
\hline $\begin{array}{r}3 \\
M\end{array}$ & $8 / 12$ & $\begin{array}{l}\text { Atrial flutter- } \\
\text { fibrillation }\end{array}$ & $\begin{array}{l}140- \\
240\end{array}$ & $\begin{array}{l}\text { Digoxin; } \\
\text { cardio- } \\
\text { version }\end{array}$ & $8 \cdot 3$ & $\begin{array}{l}\star 3 \cdot 6 \text { to } \\
1 \cdot 2\end{array}$ & $5 \cdot 5$ & +++ & $\begin{array}{l}\text { Feeding } \\
\text { difficulties }\end{array}$ \\
\hline $\begin{array}{l}4 \\
F\end{array}$ & $9 / 12$ & $\begin{array}{l}\text { Atrial flutter- } \\
\text { fibrillation }\end{array}$ & 140 & $\begin{array}{l}\text { Digoxin; } \\
\text { cardio- } \\
\text { version; } \\
\text { quinidine }\end{array}$ & $5 \cdot 5$ & $+1 \cdot 5$ & 4 & +++ & \\
\hline $\begin{array}{r}5 \\
M\end{array}$ & $106 / 12$ & $\begin{array}{l}\text { Junctional } \\
\text { rhythm; left } \\
\text { atrial rhythm }\end{array}$ & 110 & & 30 & $\begin{array}{c}\star 2 \\
4\end{array}$ & 30 & 0 & \\
\hline $\begin{array}{r}6 \\
M\end{array}$ & 17 & $\begin{array}{l}\text { Paroxysmal atrial } \\
\text { tachycardia; } \\
\text { left atrial } \\
\text { rhythm }\end{array}$ & 130 & $\begin{array}{l}\text { Oubain } \\
\text { digitalis }\end{array}$ & 66 & $\begin{array}{l}\star_{1} \cdot 2 \text { to } \\
1 \cdot 8\end{array}$ & $3 \cdot 5$ & 0 & \\
\hline $\begin{array}{r}7 \\
M\end{array}$ & $96 / 12$ & $\begin{array}{l}\text { Paroxysmal atrial } \\
\text { tachycardia; } \\
\text { junctional } \\
\text { rhythm; } \mathrm{A}-\mathrm{V} \\
\text { dissociation }\end{array}$ & 160 & Quinidine & 29 & $\begin{array}{c}\star 1.4 \\
1.7\end{array}$ to & 6 & + & \\
\hline $\begin{array}{r}8 \\
M\end{array}$ & $162 / 12$ & $\begin{array}{l}\text { Junctional } \\
\text { rhythm; ectopic } \\
\text { atrial activity }\end{array}$ & $\begin{array}{l}40- \\
130\end{array}$ & Digoxin & 50 & $\star 0.8$ & 30 & + & \\
\hline $\begin{array}{l}9 \\
\text { F }\end{array}$ & $81 / 12$ & $\begin{array}{l}\text { Paroxysmal atrial } \\
\text { tachycardia; } \\
\text { Wolf- } \\
\text { Parkinson- } \\
\text { White Type B }\end{array}$ & 240 & Digoxin & 25 & $\ddagger 0 \cdot 8$ & 18 & +++ & Bradycardia \\
\hline
\end{tabular}

$\star$ With digoxin. + With digoxin and quinidine. $¥$ Maintenance after cardioversion. $\S+++$, return to normal sinus rhythm;,++ establishment of physiolcgical ventricular rate; + , reduction in frequency of episodes of tachycardia; 0 , no effect. 

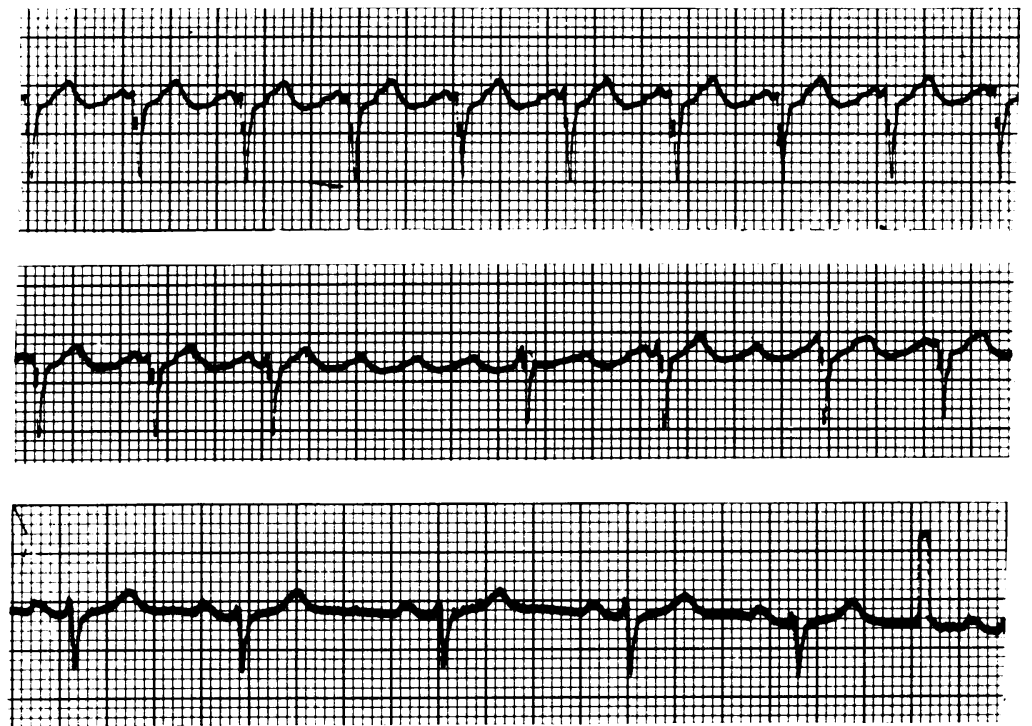

FIG. 2.-Increase in degree of $A V$ block with decrease in ventricular rate upon addition of propranolol. Normal sinus rhythm was eventually restored.

'quinidine-like action' on myocardial cells, the drug depresses the automaticity of the sinus and subsidiary pacemakers, slows the conductivity of the sinoatrial and atrioventricular junctions, and increases the refractory period of the atrioventricular node (Schamroth, 1966).

The drug of choice in treatment of supraventricular tachycardias of childhood is digoxin. Approximately $15 \%$ of patients, however, are refractory to it as well as to quinidine, cardioversion, and other modes of therapy (Linde, 1971; Nadas et al., 1952; Simcha and Bonham-Carter, 1971). Though only a minority, these patients present a serious therapeutic problem. Our experience and that of others in adults indicate that propranolol can be useful in this situation. The prime aim of treatment in these patients is the restoration of a physiological ventricular rate, rather than suppression of the ectopic rhythm (Fidelle, Cloup, and Nouaille, 1969.)

Our study indicates that in these patients with refractory supraventricular arrhythmias, significant decreases in ventricular response can be achieved by addition of propranolol. The drug was useful in a wide range of rhythm disturbances, including atrial flutter, paroxysmal atrial tachycardia, flutterfibrillation, and less defined supraventricular ectopic activity, including junctional rhythms and left atrial ectopic activity (Mirowski, 1966).

Optimal paediatric dosage of propranolol is unknown. There have been no adequate studies concerning dosage in treatment of supraventricular tachycardias in children. Amounts ranging from 20 to $120 \mathrm{mg}$ /day have been reported (Luria et al., 1966; Walters et al., 1968). Prophylaxis against return of atrial fibrillation after cardioversion was achieved with 80 to $180 \mathrm{mg}$ /day (Escudero, Martinez, and Cuan, 1969). Dosage per $\mathrm{kg}$ was not reported in these studies.

In our patients the amounts successfully employed ranged from 0.5 (Case 1) to $4 \mathrm{mg} / \mathrm{kg}$ per day (Cases 2 and 5). No optimal therapeutic dosage for all patients could be ascertained. The dosage must be individually adjusted in each patient. It appears that a rational therapeutic approach is an initial dosage of $1 \mathrm{mg} / \mathrm{kg}$ per day, gradually increasing to as high as $4 \mathrm{mg} / \mathrm{kg}$ per day until satisfactory results are obtained.

Major contraindications to the use of propranolol include cardiac failure unrelated to haemodynamic consequences of the arrhythmia, sinus bradycardia and complete heart block, pulmonary hypertension resulting in right ventricular failure (cor pulmonale), and cardiogenic shock.

In our series, propranolol has been used for up to $2 \frac{1}{2}$ years with very few side effects observed. No patient required discontinuation of the drug. Undesirable side-effects reported by others include (1) light-headedness, rashes, visual disturbances, purpura, and paraesthesiae; (2) those due to 
specific pharmacological action of the drug, such as hypotension, bradycardia, cardiac failure, dyspnoea, and wheezing; and (3) biochemical abnormalities including a rise in BUN, SGOT, sodium retention, and aggravation of hypoglycaemia (Stephen, 1966). When propranolol is administered intravenously, an isoprenaline drip should be available to overcome $\beta$-adrenergic blocking effects if necessary.

Positive conclusions based upon our study must be made with caution. Ideally, our patient population would be more homogeneous with respect to age, arrhythmia, and management before propranolol therapy. Precise and quantitative evaluation of efficacy of propranolol is made difficult by concomitant use of digoxin, though digoxin alone was clearly ineffective in controlling ventricular rate. Encouraging results from this study indicate, however, that propranolol is a useful adjunct in the treatment of childhood supraventricular arrhythmias refractory to conventional therapy.

The authors thank Dr. Richard D. Rowe, The Johns Hopkins Hospital, for reviewing the manuscript and for his helpful suggestions. This work was supported in part by General Research Grant 5SOIFR-05478-08 and RR5378 from the U.S. Public Health Service, National Institute of Health.

\section{REFERENCES}

Escudero, J., Martinez, C. S., and Cuan, P. M. (1969). Propranolol in the prevention of auricular fibrillation setbacks after cardioversion. Archivos del Instituto de Cardiologia de México, 39, 266.

Fidelle, J., Cloup, M., and Nouaille, J. (1969). Prolonged supraventricula ectopic tachycardia in the child. Annales de Pédiatrie, 16, 687.

Linde, L. (1971). Present status and treatment of supraventricular tachycardia. Cardiology and Pneumology, 9, 101

Luria, M. H., Adelson, E. I., and Miller, A. J. (1966). Acute and chronic effects of an adrenergic beta-receptor blocking agent (propranolol) in treatment of cardiac arrhythmias. Circulation, $34,767$.

Mirowski, M. (1966). Left atrial rhythm; diagnostic criteria and differentiation from nodal arrhythmias. American fournal of Cardiology, 17, 203.

Nadas, A. S., Daeschner, C. W., Roth, A., and Blumenthal, S. L. (1952). Paroxysnal tachycardia in infants and children: study of 41 cases. Pediatrics, 9, 167.

Schamroth, L. (1966). Immediate effects of intravenous propranolol on various cardiac arrhythmias. American fournal of Cardiology, 18, 438 .

Simcha, A., and Bonham-Carter, R. E. (1971). Paroxysmal atrial tachycardia in infants and children. Lancet, 1, 832.

Sloman, G., and Stannard, M. (1967). Beta-adrenergic blockade and cardiac arrhythmias. British Medical fournal, 4, 508.

Stephen, S. A. (1966). Unwanted effects of propranolol. American fournal of Cardiology, 18, 463.

Walters, L., Geptes, L. S., Noonan, J. A., and Surawicz, B. (1968). Long-term management of chronic tachycardias of childhood with daily administered propranolol. (Abst.) American fournal of Cardiology, 21, 119.

Wennevold, A., and Sandoe, E. (1966). The anti-arrhythmic effect of propranolol. Acta Medica Scandinavica, 180, 715.

Correspondence to Dr. Barbara B. Bell, Department of Pediatrics, The Johns Hopkins Hospital, Baltimore, Maryland 21205, U.S.A. 